\title{
Synthesis and Characterization of 2,6-Di(quinolin-8-
}

\section{yl)pyridines. New Ligands for Bistridentate $\mathrm{Ru}^{\mathrm{II}}$ \\ Complexes with $\mu$ s Luminescent Lifetimes}

\author{
Michael Jäger, ${ }^{\dagger}$ Lars Eriksson, ${ }^{*}$ Jonas Bergquist,$^{\S}$ and Olof Johansson ${ }^{\dagger}{ }^{\dagger}$ \\ ${ }^{\dagger}$ Department of Photochemistry and Molecular Science, Uppsala University, Box 523, 75120 Uppsala, \\ Sweden \\ ${ }^{*}$ Department of Physical, Inorganic and Structural Chemistry, Stockholm University, 10691 Stockholm, \\ Sweden \\ $\S$ Department of Physical and Analytical Chemistry, Uppsala University, Box 599, 75124 Uppsala, \\ Sweden
}

olof.johansson@fotomol.uu.se

Table of contents:

Experimental details, characterizations for compounds 3-6 and 8-10 S3-S6

${ }^{1} \mathrm{H}$ NMR and ${ }^{13} \mathrm{C}$ spectra of compound $2\left(\mathrm{CDCl}_{3}\right) .400 \mathrm{MHz} \quad$ S7

Compound $3\left(\mathrm{CDCl}_{3}\right)$. $\quad$ S8

Compound $4\left(\mathrm{CDCl}_{3}\right)$ S9

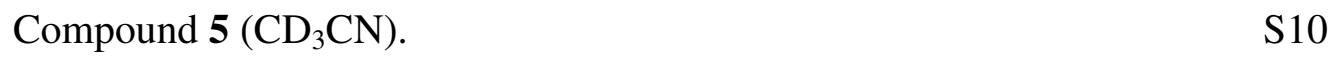

$\begin{array}{lr}\text { Compound } 6\left(\mathrm{CDCl}_{3}\right) \text {. } & \mathrm{S} 11\end{array}$

$\begin{array}{lr}\text { Compound } 7\left(\mathrm{CDCl}_{3}\right) \text { S12 } & \text { S12 }\end{array}$

$\begin{array}{lr}\text { Compound } \mathbf{8}\left(\mathrm{CDCl}_{3}\right) \text {. } & \mathrm{S} 13\end{array}$ 
2,4-Di(quinolin-8-yl)-6-(p-tolyl)-pyridine $\left(\mathrm{CDCl}_{3}\right) . \quad \mathrm{S} 14$

$\begin{array}{ll}\text { Compound } 9\left(\mathrm{CDCl}_{3}\right) \text {. } & \mathrm{S} 15\end{array}$

$\begin{array}{lr}\text { Compound } 10\left(\mathrm{CDCl}_{3}\right) . & \mathrm{S} 16\end{array}$

$\begin{array}{lr}\text { Compound } 11\left(\mathrm{CDCl}_{3}\right) . & \mathrm{S} 17\end{array}$

$\begin{array}{lr}\text { Crystallographic data for } \mathbf{1} \text { and } \mathbf{5} & \text { S18-S19 }\end{array}$

$\begin{array}{lr}\text { Crystal packing in } \mathbf{1} & \text { S20 }\end{array}$

$\begin{array}{ll}\text { Crystal packing in } \mathbf{5} & \text { S21-S22 }\end{array}$

Geometry optimization calculation of $\mathbf{1} \quad$ S23

$\begin{array}{ll}\text { References } & \text { S24 }\end{array}$ 


\section{Experimental Section.}

Commercial reagents and solvents were used as received except potassium phosphate which was finely ground before use, toluene which was freshly distilled from sodium, and DMF distilled from calcium hydride. 2,6-Di(quinolin-8-yl)pyridine (1), ${ }^{1} \quad 8$-acetylquinoline, ${ }^{2}$ and $\left[\mathrm{Ru}(\mathbf{1})_{2}\right]\left[\mathrm{PF}_{6}\right]_{2}{ }^{1}$ were prepared as described previously. NMR spectra were recorded on a $400 \mathrm{MHz}$ spectrometer at $293 \mathrm{~K}$. LCMS was performed on an analytical C18 column $(150 \times 3.0 \mathrm{~mm}, 5 \mu)$ with $0.05 \% \mathrm{HCO}_{2} \mathrm{H}_{\text {in }} \mathrm{H}_{2} \mathrm{O}$ and $0.05 \% \mathrm{HCO}_{2} \mathrm{H}$ in $\mathrm{CH}_{3} \mathrm{CN}$ as eluents and the LC flow was coupled to a mass spectrometer with electrospray ionization (ESI). Preparative HPLC was performed on a C18 column (150 x $21.2 \mathrm{~mm}, 10$ $\mu)$ with $0.1 \% \mathrm{HCO}_{2} \mathrm{H}$ in $\mathrm{H}_{2} \mathrm{O}$ and $0.1 \% \mathrm{HCO}_{2} \mathrm{H}$ in $\mathrm{CH}_{3} \mathrm{CN}$ as eluents. High-resolution ESI-MS were performed on a superconducting 9.4 T FTICR mass spectrometer equipped with an in-house developed emitter. $^{3}$

General Procedure for the Pd-Catalyzed Coupling (1-4): Quinoline-8-boronic acid (2.02 mmol), the corresponding 2,6-dihalopyridine $(1.00 \mathrm{mmol}), \mathrm{Pd}(\mathrm{dba})_{2}(0.01 \mathrm{mmol}, 0.5 \%)$, 2-dicyclohexylphosphino2',6'-dimethoxybiphenyl $(0.02 \mathrm{mmol}, 1 \%)$, and finely ground potassium phosphate $(5.00 \mathrm{mmol})$ were suspended in dry toluene. The mixture was purged with argon and heated at $110{ }^{\circ} \mathrm{C}$ over night. The dark yellow reaction mixture was cooled to room temperature, poured into $\mathrm{Et}_{2} \mathrm{O}(150 \mathrm{~mL})$, and was left stirring for $30 \mathrm{~min}$. The mixture was filtered, concentrated in vacuo, and the remaining solid purified by recrystallization or column chromatography.

4-Hydroxymethyl-2,6-di(quinolin-8-yl)pyridine (3). Purification by preparative HPLC afforded 3 in $43 \%$ isolated yield. ${ }^{1} \mathrm{H} \mathrm{NMR}\left(\mathrm{CDCl}_{3}\right): \delta 8.85(2 \mathrm{H}, \mathrm{dd}, J=4.2,1.8 \mathrm{~Hz}), 8.12(2 \mathrm{H}, \mathrm{dd}, J=7.2,1.5 \mathrm{~Hz})$, $8.09(2 \mathrm{H}, \mathrm{dd}, J=8.3,1.8 \mathrm{~Hz}), 7.88(2 \mathrm{H}, \mathrm{s}), 7.73(2 \mathrm{H}, \mathrm{dd}, J=8.2,1.5 \mathrm{~Hz}), 7.52(2 \mathrm{H}, \mathrm{dd}, J=8.2,7.2$ $\mathrm{Hz}), 7.29(2 \mathrm{H}, \mathrm{dd}, J=8.3,4.2 \mathrm{~Hz}), 4.87(1 \mathrm{H}, \mathrm{s}, \mathrm{br}), 4.63(2 \mathrm{H}, \mathrm{s}) .{ }^{13} \mathrm{C} \mathrm{NMR}\left(\mathrm{CDCl}_{3}\right): \delta 156.7,150.0$, $149.7,145.7,139.3,136.4,131.5,128.5,128.3,126.4,122.9,120.8,63.2 . \mathrm{MS}(\mathrm{ESI}): \mathrm{m} / z, 364$ $\left(\left[\mathrm{M}+\mathrm{H}^{+}\right]^{+}\right)$. Anal. Calcd for $\mathrm{C}_{24} \mathrm{H}_{17} \mathrm{~N}_{3} \mathrm{O}: \mathrm{C}, 79.32 ; \mathrm{H}, 4.72 ; \mathrm{N}, 11.56$. Found: C, 79.05; H, 4.62; N, 11.39. 
4-Nitro-2,6-di(quinolin-8-yl)pyridine (4). Purification by column chromatography (silica gel, $\left.\mathrm{CH}_{2} \mathrm{Cl}_{2} / 2-4 \% \mathrm{MeOH}\right)$ afforded 4 in $54 \%$ isolated yield. ${ }^{1} \mathrm{H} \mathrm{NMR}\left(\mathrm{CDCl}_{3}\right): \delta 9.04(2 \mathrm{H}, \mathrm{dd}, J=4.2,1.9$ Hz), $9.03(2 \mathrm{H}, \mathrm{s}), 8.39(2 \mathrm{H}, \mathrm{dd}, J=7.2,1.5 \mathrm{~Hz}), 8.28(2 \mathrm{H}, \mathrm{dd}, J=8.3,1.9 \mathrm{~Hz}), 7.96(2 \mathrm{H}, \mathrm{dd}, J=8.2$, $1.5 \mathrm{~Hz}), 7.71(2 \mathrm{H}, \mathrm{dd}, J=8.2,7.2 \mathrm{~Hz}), 7.51(2 \mathrm{H}, \mathrm{dd}, J=8.3,4.2 \mathrm{~Hz}) .{ }^{13} \mathrm{C} \mathrm{NMR}\left(\mathrm{CDCl}_{3}\right): \delta 159.0$, $153.5,150.8,145.8,137.2,136.8,131.9,129.9,128.8,126.7,121.5,118.4$. HRMS (ESI): $m / z 379.1187$ $\left(\left[\mathrm{M}+\mathrm{H}^{+}\right]^{+}\right)$calcd for $\mathrm{C}_{23} \mathrm{H}_{15} \mathrm{~N}_{4} \mathrm{O}_{2} 379.1195$.

4-Amino-2,6-di(quinolin-8-yl)pyridine (5). To a suspension of 4 (0.194 g, $0.51 \mathrm{mmol})$ and palladium on charcoal (0.026 g, 5\% TypF $116 \mathrm{R} / \mathrm{W}$ Degussa) in EtOH $(50 \mathrm{~mL})$ was added hydrazine hydrate $(0.5$ $\mathrm{mL})$. The mixture was heated at reflux under a nitrogen atmosphere, after one hour additional hydrazine hydrate $(0.5 \mathrm{~mL})$ was added and the course of the reaction was followed by TLC. When full conversion was achieved, the hot orange solution was filtered through a Celite plug and concentrated in vacuo. To the residue was added $\mathrm{CHCl}_{3}(50 \mathrm{~mL})$ and the mixture was refluxed for $30 \mathrm{~min}$. The suspension was cooled to room temperature and the solid was filtered off and dried in vacuo to afford $\mathbf{5}$ as an off-white powder $(0.162 \mathrm{~g}, 90 \%) .{ }^{1} \mathrm{H}$ NMR $\left(\mathrm{CD}_{3} \mathrm{CN}\right): \delta 8.74(2 \mathrm{H}, \mathrm{dd}, J=4.2,1.8 \mathrm{~Hz}), 8.53(2 \mathrm{H}, \mathrm{dd}, J=8.4,1.8$ $\mathrm{Hz}), 8.43(2 \mathrm{H}, \mathrm{dd}, J=7.4,1.4 \mathrm{~Hz}), 8.24(2 \mathrm{H}, \mathrm{dd}, J=8.2,1.4 \mathrm{~Hz}), 7.86(2 \mathrm{H}, \mathrm{dd}, J=8.2,7.4 \mathrm{~Hz}), 7.66$ $(2 \mathrm{H}, \mathrm{dd}, J=8.4,4.2 \mathrm{~Hz}), 7.61(2 \mathrm{H}, \mathrm{s}), 6.76\left(2 \mathrm{H}, \mathrm{br}, \mathrm{NH}_{2}\right) .{ }^{13} \mathrm{C} \mathrm{NMR}\left(\mathrm{CD}_{3} \mathrm{CN}\right): \delta 157.5,154.4,151.2$, 146.8, 140.1, 137.5, 131.6, 129.6 (two overlapping signals), 127.3, 122.2, 112.0. HRMS (ESI): $\mathrm{m} / z$ $349.1445\left(\left[\mathrm{M}+\mathrm{H}^{+}\right]^{+}\right)$calcd for $\mathrm{C}_{23} \mathrm{H}_{17} \mathrm{~N}_{4} 349.1453$.

4-Bromo-2,6-di(quinolin-8-yl)pyridine (6). To a suspension of 5 (0.207 g, $0.59 \mathrm{mmol})$ and copper(II) bromide $(0.325 \mathrm{~g}, 1.46 \mathrm{mmol})$ in $\mathrm{CH}_{3} \mathrm{CN}(20 \mathrm{~mL})$ was added tert-butyl nitrite $(0.5 \mathrm{~mL})$. The suspension was heated at reflux under a nitrogen atmosphere over night. After cooling to room temperature excessive solvent was removed in vacuo, and the crude product stirred in a mixture of an aqueous EDTA solution $(3 \mathrm{~g}, 100 \mathrm{~mL})$ and $\mathrm{CH}_{2} \mathrm{Cl}_{2}(50 \mathrm{~mL})$ and filtered. The aqueous layer was extracted with additional $\mathrm{CH}_{2} \mathrm{Cl}_{2}$ and the combined organic layers concentrated in vacuo. Recrystallization from $\mathrm{MeOH}$ yielded an off-white solid $(0.201 \mathrm{~g}, 82 \%) .{ }^{1} \mathrm{H} \mathrm{NMR}\left(\mathrm{CDCl}_{3}\right): \delta 9.03(2 \mathrm{H}, \mathrm{dd}, J=4.2,1.8 \mathrm{~Hz})$, $8.37(2 \mathrm{H}, \mathrm{s}), 8.27(2 \mathrm{H}, \mathrm{dd}, J=7.2,1.5 \mathrm{~Hz}), 8.24(2 \mathrm{H}, \mathrm{dd}, J=8.3,1.8 \mathrm{~Hz}), 7.90(2 \mathrm{H}, \mathrm{dd}, J=8.2,1.5$ 
$\mathrm{Hz}), 7.66(2 \mathrm{H}, \mathrm{dd}, J=8.2,7.2 \mathrm{~Hz}), 7.47(2 \mathrm{H}, \mathrm{dd}, J=8.3,4.2 \mathrm{~Hz}) .{ }^{13} \mathrm{C} \mathrm{NMR}\left(\mathrm{CDCl}_{3}\right): \delta 157.8,150.6$, 145.9, 138.1, 136.6, 131.8, 131.6, 129.2, 128.7 (two overlapping signals), 126.7, 121.3. MS (ESI): $\mathrm{m} / \mathrm{z}$ $414\left(\left[\mathrm{M}+\mathrm{H}^{+}\right]^{+}\right)$calcd for $\mathrm{C}_{23} \mathrm{H}_{15}{ }^{81} \mathrm{BrN}_{3}$ 414. Anal. Calcd for $\mathrm{C}_{23} \mathrm{H}_{14} \mathrm{BrN}_{3}: \mathrm{C}, 67.00 ; \mathrm{H}, 3.42 ; \mathrm{N}, 10.19$. Found: C, 66.72; H, 3.27; N, 10.13 .

General procedure for the ring cyclization reaction (7-10): 8-Acetylquinoline (1.64 mmol) and the corresponding substituted benzaldehyde $(0.81 \mathrm{mmol})$ were dissolved in EtOH $(1 \mathrm{~mL})$. A solution of potassium hydroxide $(1.62 \mathrm{mmol}, 85 \%)$ in aqueous ammonia $(1 \mathrm{~mL}, 28 \%)$ was added. The reaction mixture was warmed at $40{ }^{\circ} \mathrm{C}$ over night.

2,6-Di(quinolin-8-yl)-4-(p-tolyl)-pyridine (8). The crude reaction mixture was concentrated in vacuo, $\mathrm{H}_{2} \mathrm{O}$ and $\mathrm{CHCl}_{3}$ were added and the organic phase separated. After removal of solvent, the residue was purified by column chromatography (silica gel, $\mathrm{CH}_{2} \mathrm{Cl}_{2} / 2.5-3.5 \% \mathrm{MeOH}$ ) to give $\mathbf{8}$ as an off-white powder in $26 \%$ isolated yield. ${ }^{1} \mathrm{H}$ NMR $\left(\mathrm{CDCl}_{3}\right): \delta 9.01(2 \mathrm{H}, \mathrm{dd}, J=4.2,1.8 \mathrm{~Hz}), 8.32(2 \mathrm{H}, \mathrm{s}), 8.30$ $(2 \mathrm{H}, \mathrm{dd}, J=7.2,1.5 \mathrm{~Hz}), 8.25(2 \mathrm{H}, \mathrm{dd}, J=8.3,1.8 \mathrm{~Hz}), 7.90(2 \mathrm{H}, \mathrm{dd}, J=8.2,1.5 \mathrm{~Hz}), 7.76-7.72(2 \mathrm{H}$, m, AA' part of AA'XX'), $7.68(2 \mathrm{H}, \mathrm{dd}, J=8.2,7.2 \mathrm{~Hz}), 7.46(2 \mathrm{H}, \mathrm{dd}, J=8.3,4.2 \mathrm{~Hz}), 7.32-7.28(2 \mathrm{H}$, m, XX' part of $\left.\mathrm{AA}^{\prime} \mathrm{XX} X^{\prime}\right), 2.42(3 \mathrm{H}, \mathrm{s}) .{ }^{13} \mathrm{C} \mathrm{NMR}\left(\mathrm{CDCl}_{3}\right): \delta 157.3,150.3,147.1,146.1,139.7,138.6$, $136.5,136.4,131.6,129.7,128.7,128.6,127.5,126.6,123.7,121.0,21.4 . \mathrm{MS}(\mathrm{ESI}): \mathrm{m} / z \quad 425$ $\left(\left[\mathrm{M}+\mathrm{H}^{+}\right]^{+}\right)$. Anal. Calcd for $\mathrm{C}_{30} \mathrm{H}_{21} \mathrm{~N}_{3}$ : C, 85.08; H, 5.00; N, 9.92. Found: C, 84.74; H, 4.98; N, 9.79.

2,4-Di(quinolin-8-yl)-6-(p-tolyl)-pyridine. ${ }^{1} \mathrm{H}$ NMR $\left(\mathrm{CDCl}_{3}\right): \delta 8.98-8.94(2 \mathrm{H}, \mathrm{m}), 8.42(1 \mathrm{H}, \mathrm{dd}, J=$ $7.2,1.5 \mathrm{~Hz}), 8.41(1 \mathrm{H}, \mathrm{d}, J=1.5 \mathrm{~Hz}), 8.22(1 \mathrm{H}, \mathrm{dd}, J=8.3,1.9 \mathrm{~Hz}), 8.20(1 \mathrm{H}, \mathrm{dd}, J=8.3,1.9 \mathrm{~Hz}), 8.13$ $(1 \mathrm{H}, \mathrm{d}, J=1.5 \mathrm{~Hz}), 8.11-8.08\left(2 \mathrm{H}, \mathrm{m}, \mathrm{AA}^{\prime}\right.$ part of AA'XX'), $8.00(1 \mathrm{H}, \mathrm{dd}, J=7.2,1.5 \mathrm{~Hz}), 7.90(1 \mathrm{H}$ $\mathrm{dd}, J=8.2,1.5 \mathrm{~Hz}), 7.89(1 \mathrm{H}, \mathrm{dd}, J=8.2,1.5 \mathrm{~Hz}), 7.72(1 \mathrm{H}, \mathrm{dd}, J=8.2,7.2 \mathrm{~Hz}), 7.67(1 \mathrm{H}, \mathrm{dd}, J=8.2$ $7.2 \mathrm{~Hz}), 7.43(1 \mathrm{H}, \mathrm{dd}, J=8.3,4.2 \mathrm{~Hz}), 7.39(1 \mathrm{H}, \mathrm{dd}, J=8.3,4.2 \mathrm{~Hz}), 7.32-7.28\left(2 \mathrm{H}, \mathrm{m}, \mathrm{XX}{ }^{\prime}\right.$ part of AA'XX'), $2.42(3 \mathrm{H}, \mathrm{s}) .{ }^{13} \mathrm{C}$ NMR $\left(\mathrm{CDCl}_{3}\right): \delta 157.1,156.3,150.6,150.3,147.2,146.2,145.9,139.7$, 139.1, 138.4, 137.7, 136.4 (two overlapping signals), 131.9, 130.8, 129.4, 128.8 (two overlapping signals), 128.7, 128.6, 127.4 (two overlapping signals), 126.7, 126.5, 121.4, 121.3, 121.0, 21.4. HRMS (ESI): $m / z 424.1805\left(\left[\mathrm{M}+\mathrm{H}^{+}\right]^{+}\right)$calcd for $\mathrm{C}_{30} \mathrm{H}_{22} \mathrm{~N}_{3} 424.1814$. 
4-(p-Cyanophenyl)-2,6-di(quinolin-8-yl)pyridine (9). The solid was filtered off and recrystallized twice from EtOH to afford 9 as an off-white powder in $23 \%$ isolated yield. ${ }^{1} \mathrm{H}$ NMR $\left(\mathrm{CDCl}_{3}\right): \delta 9.01$ $(2 \mathrm{H}, \mathrm{dd}, J=4.2,1.8 \mathrm{~Hz}), 8.38(2 \mathrm{H}, \mathrm{s}), 8.34(2 \mathrm{H}, \mathrm{dd}, J=7.2,1.5 \mathrm{~Hz}), 8.26(2 \mathrm{H}, \mathrm{dd}, J=8.3,1.8 \mathrm{~Hz})$, 7.95-7.91 (2H, m, AA' part of AA'MM'), $7.92(2 \mathrm{H}, \mathrm{dd}, J=8.2,1.5 \mathrm{~Hz}), 7.81-7.77\left(2 \mathrm{H}, \mathrm{m}, \mathrm{MM}^{\prime}\right.$ part of AA'MM'), $7.69(2 \mathrm{H}, \mathrm{dd}, J=8.2,7.2 \mathrm{~Hz}), 7.47(2 \mathrm{H}, \mathrm{dd}, J=8.3,4.2 \mathrm{~Hz}) .{ }^{13} \mathrm{C} \mathrm{NMR}\left(\mathrm{CDCl}_{3}\right): \delta 157.7$, $150.5,146.0,145.2,144.1,138.9,136.7,132.8,131.8,129.0,128.8,128.4,126.8,123.9,121.2,118.9$, 112.3. MS (ESI): $m / z 436\left(\left[\mathrm{M}+\mathrm{H}^{+}\right]^{+}\right)$. Anal. Calcd for $\mathrm{C}_{30} \mathrm{H}_{18} \mathrm{~N}_{4}: \mathrm{C}, 82.93 ; \mathrm{H}, 4.18 ; \mathrm{N}, 12.89$. Found: $\mathrm{C}$, 82.53; H, 4.30; N, 12.72 .

4-(2,5-Dimethoxyphenyl)-2,6-di(quinolin-8-yl)pyridine (10). The crude reaction mixture was concentrated in vacuo, $\mathrm{H}_{2} \mathrm{O}$ and $\mathrm{CHCl}_{3}$ were added and the organic phase separated. After removal of solvent, the residue was purified by preparative HPLC to give $\mathbf{1 0}$ as a white powder in $23 \%$ isolated yield. ${ }^{1} \mathrm{H}$ NMR $\left(\mathrm{CDCl}_{3}\right): \delta$ 9.01-8.98 $(2 \mathrm{H}, \mathrm{dm}, J=4.2 \mathrm{~Hz}), 8.35(2 \mathrm{H}, \mathrm{s}), 8.35-8.32(2 \mathrm{H}, \mathrm{dm}, J=7.2 \mathrm{~Hz})$, 8.20-8.17 (2H, dm, $J=8.3 \mathrm{~Hz}), 7.87-7.84(2 \mathrm{H}, \mathrm{dm}, J=8.3 \mathrm{~Hz}), 7.67(2 \mathrm{H}, \mathrm{dd}, J=8.3,7.2 \mathrm{~Hz}), 7.40$ $(2 \mathrm{H}, \mathrm{dd}, J=8.3,4.2 \mathrm{~Hz}), 7.26(1 \mathrm{H}, \mathrm{d}, J=2.8 \mathrm{~Hz}), 6.97-6.93(1 \mathrm{H}, \mathrm{m}), 6.93-6.89(1 \mathrm{H}, \mathrm{dm}, J=2.8 \mathrm{~Hz})$, $3.82(6 \mathrm{H}, \mathrm{s}) .{ }^{13} \mathrm{C} \mathrm{NMR}\left(\mathrm{CDCl}_{3}\right): \delta 156.6,153.8,151.2,150.2,146.1,144.7,139.7,136.3,131.6,129.6$,

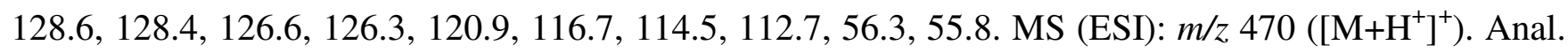
Calcd for $\mathrm{C}_{31} \mathrm{H}_{23} \mathrm{~N}_{3} \mathrm{O}_{2}$ : C, 79.30; H, 4.94; N, 8.95. Found: C, 79.05; H, 4.83; N, 8.69. 

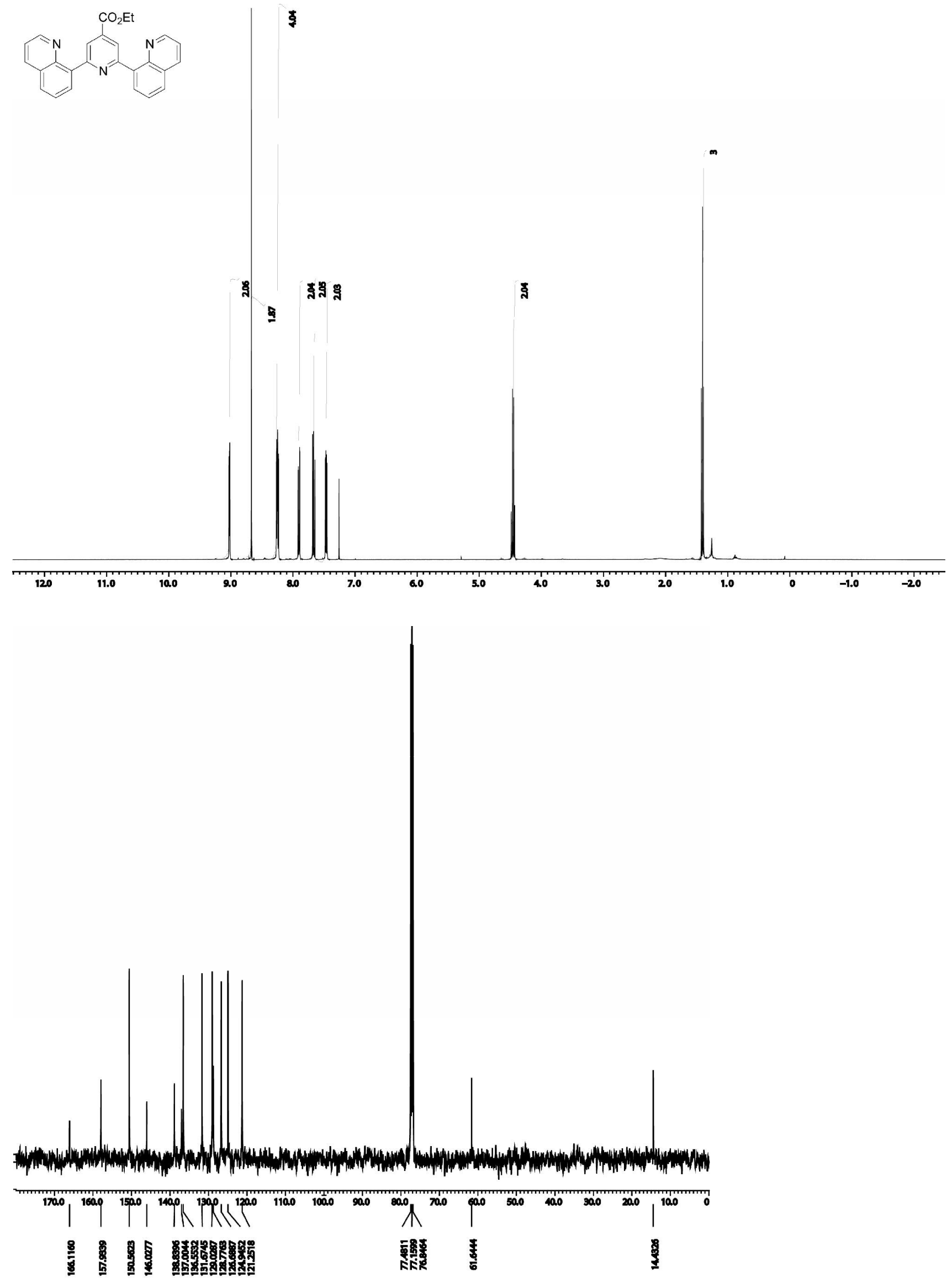

Compound $2\left(\mathrm{CDCl}_{3}\right)$. 


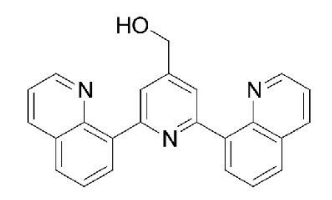

s
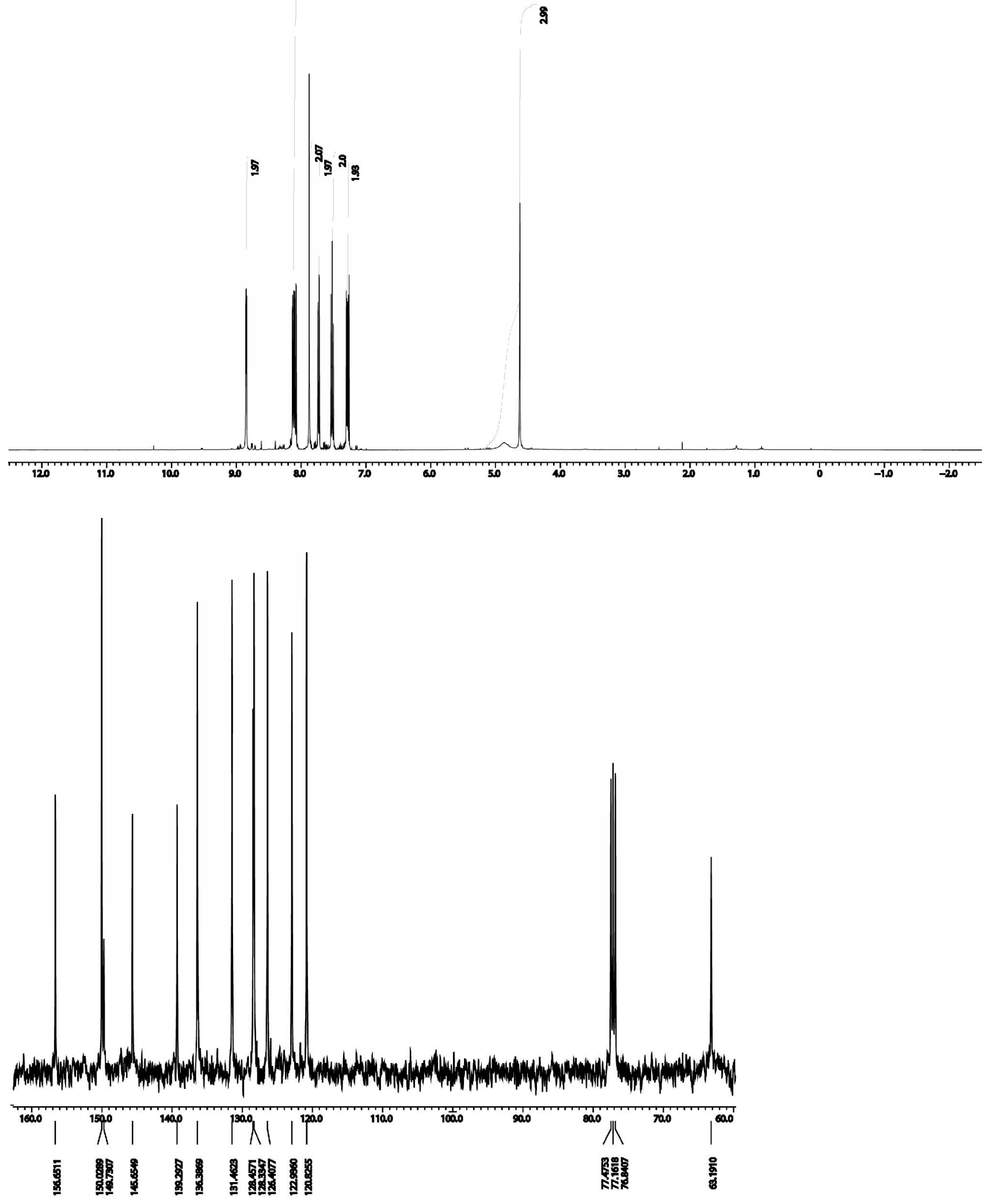

Compound $3\left(\mathrm{CDCl}_{3}\right)$.

SB 

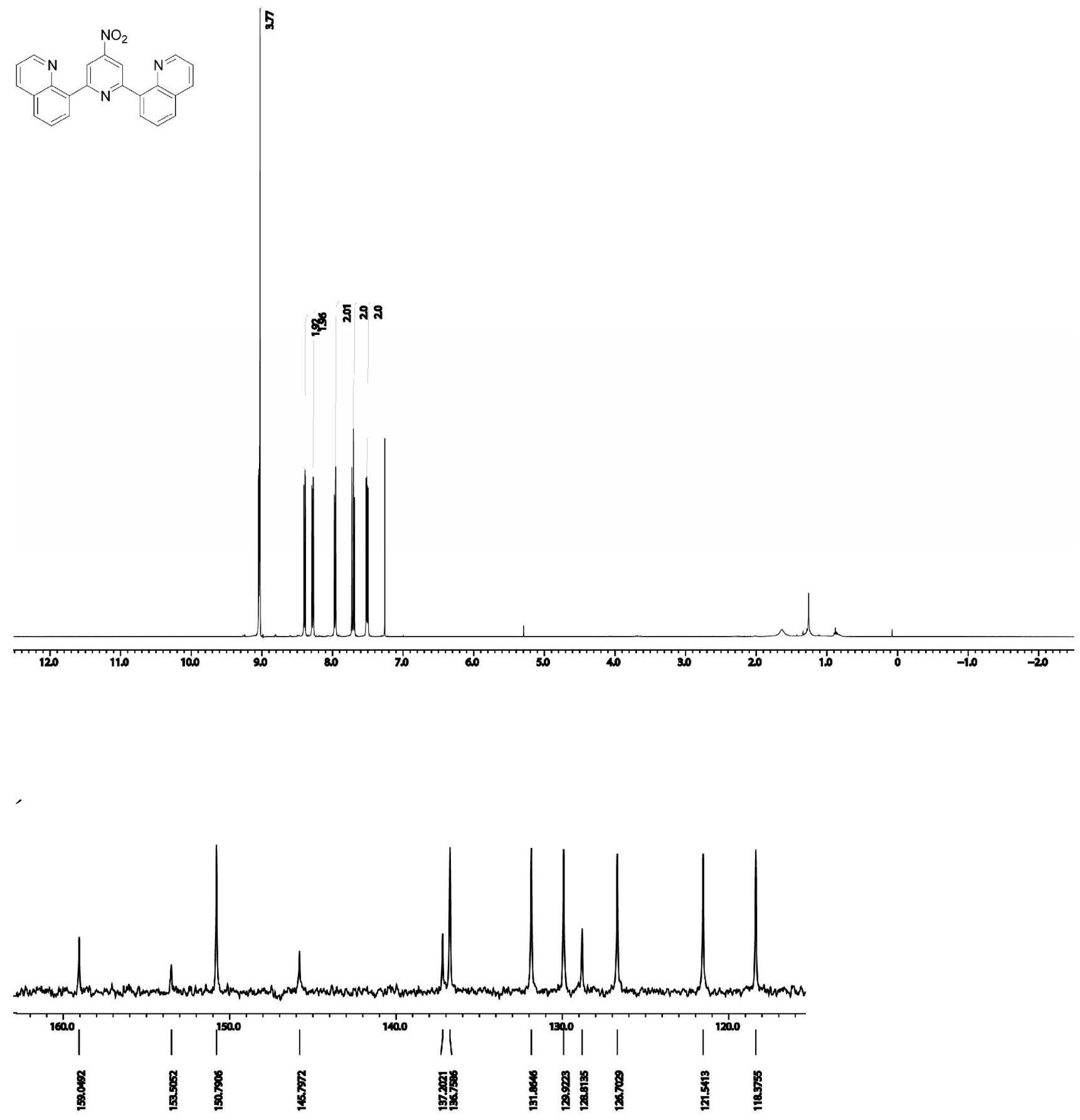

Compound $4\left(\mathrm{CDCl}_{3}\right)$. 

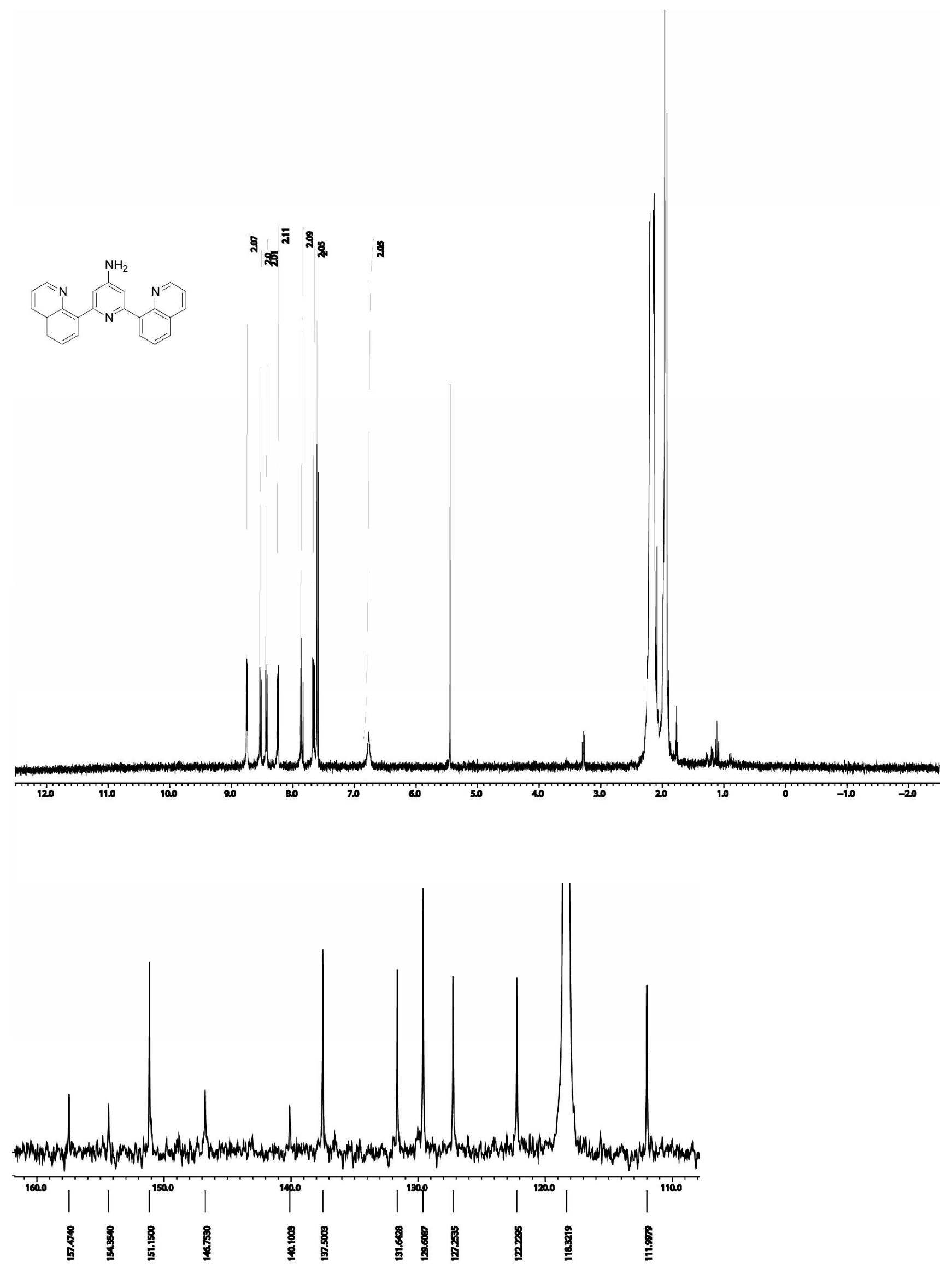

Compound $5\left(\mathrm{CD}_{3} \mathrm{CN}\right)$. (Poor solubility of $\mathbf{5}$, residual acetone at 2.1 and $\mathrm{CH}_{2} \mathrm{Cl}_{2}$ at $5.4 \mathrm{ppm}$.) 

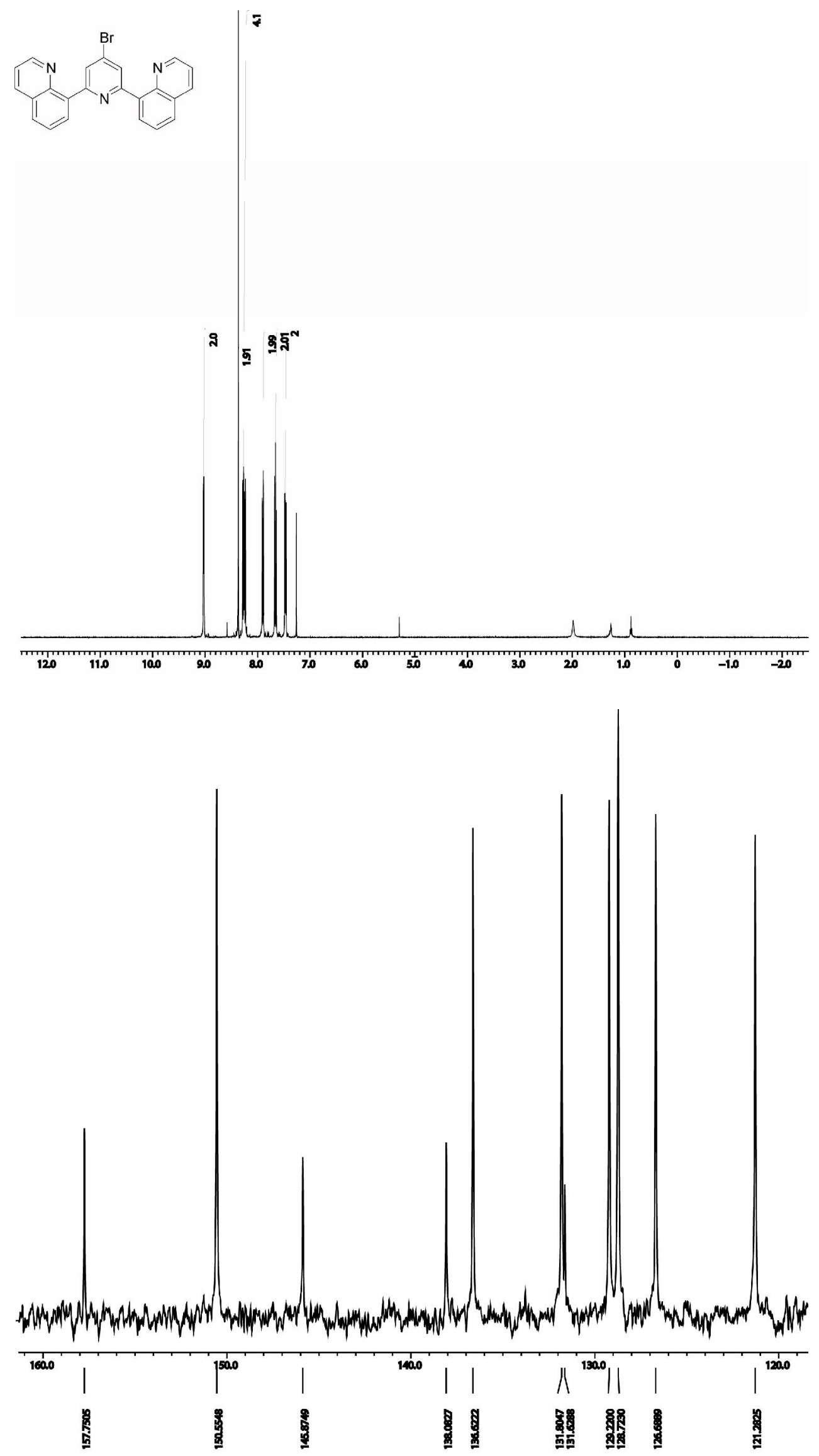

Compound $6\left(\mathrm{CDCl}_{3}\right)$. 

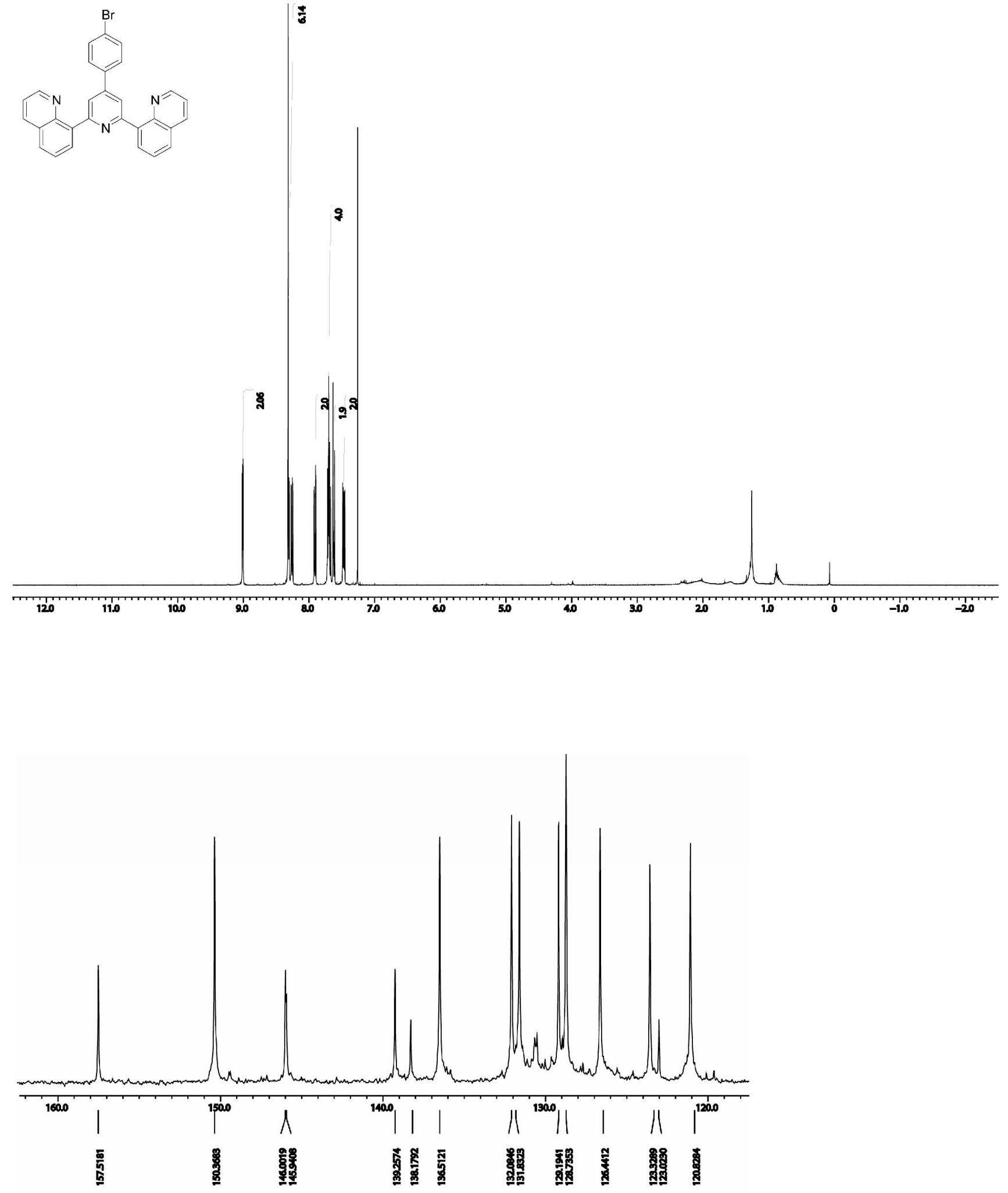

Compound $7\left(\mathrm{CDCl}_{3}\right)$. 

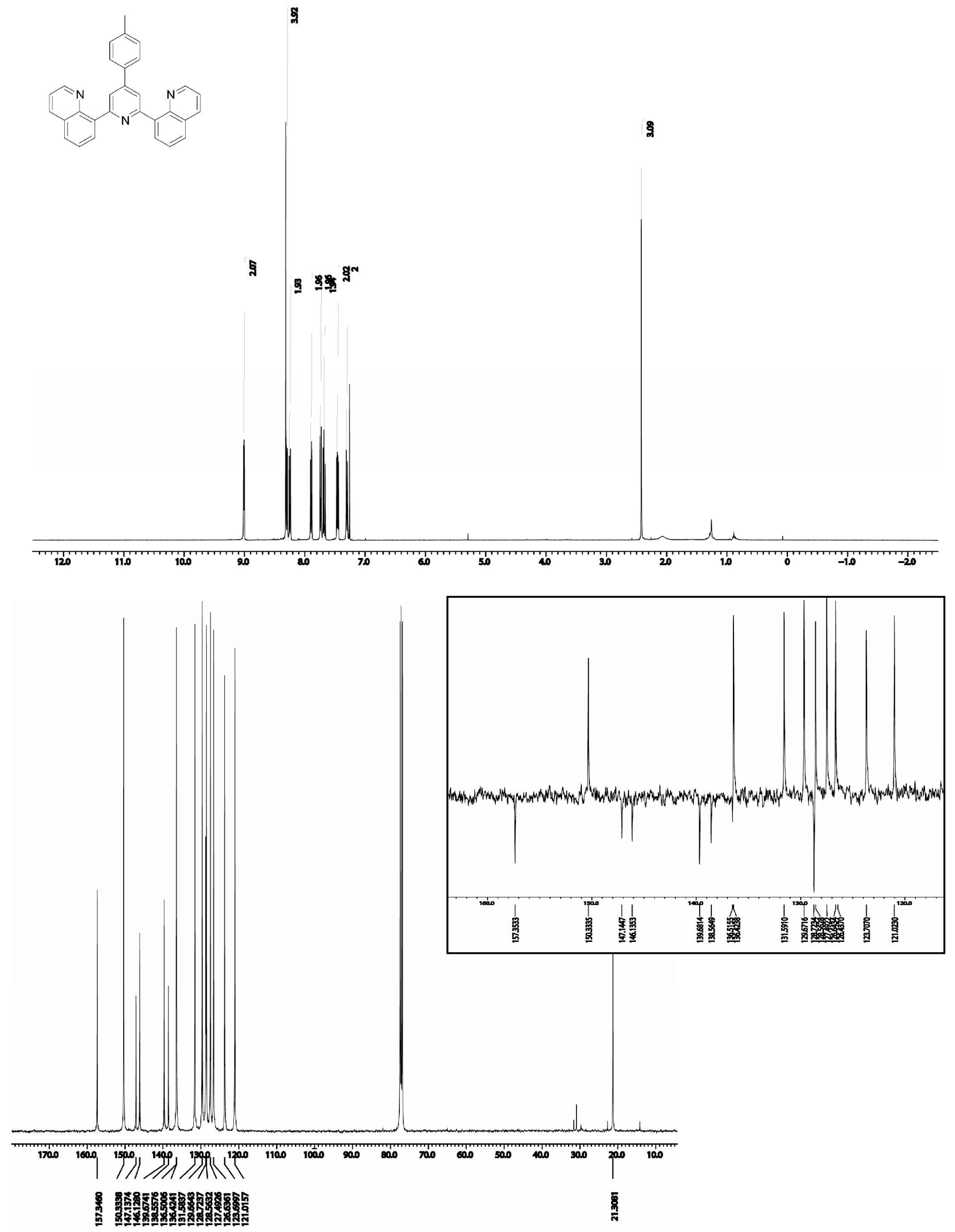

Compound $8\left(\mathrm{CDCl}_{3}\right)$. 

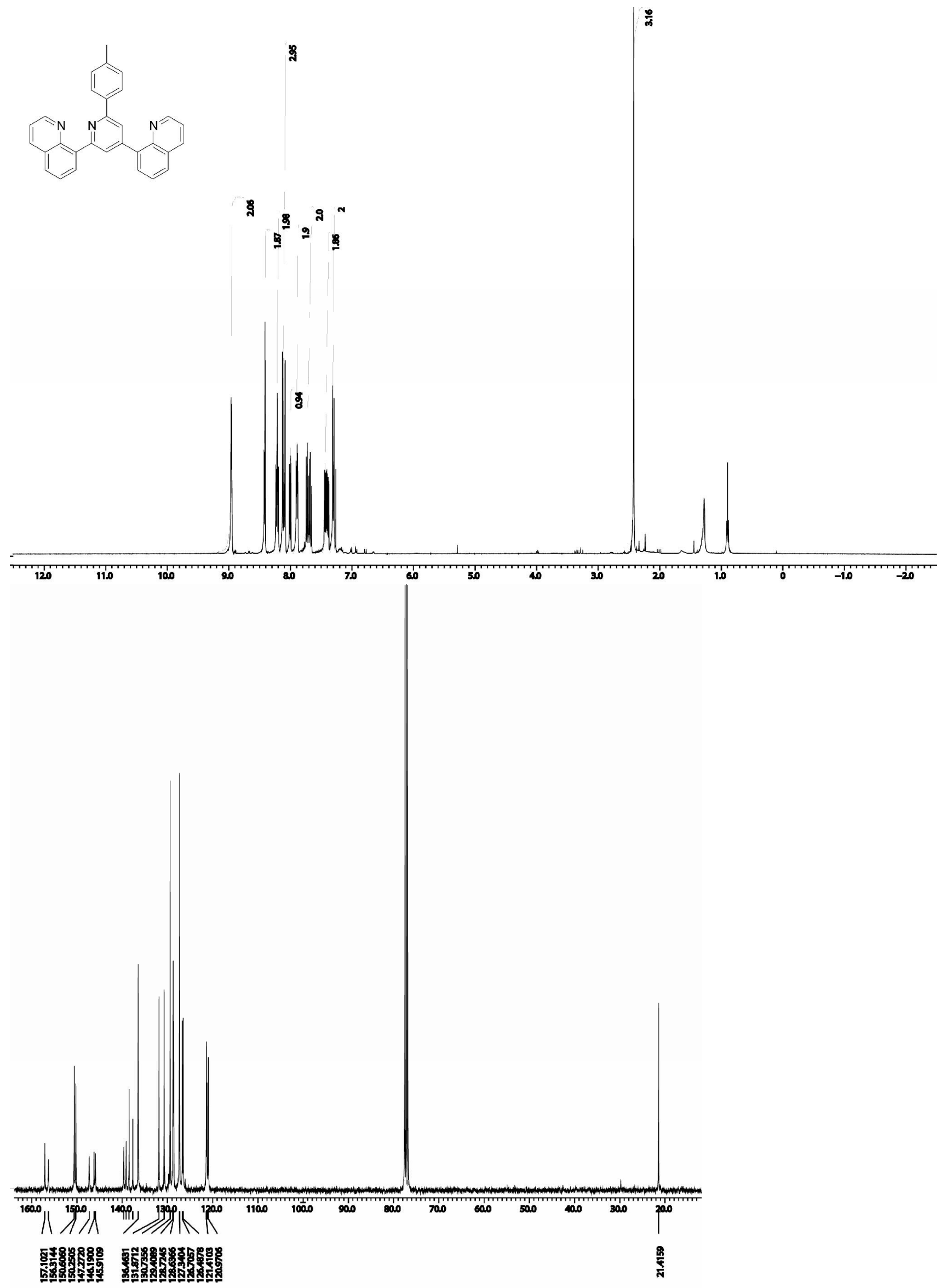

2,4-Di(quinolin-8-yl)-6-(p-tolyl)-pyridine $\left(\mathrm{CDCl}_{3}\right)$. 

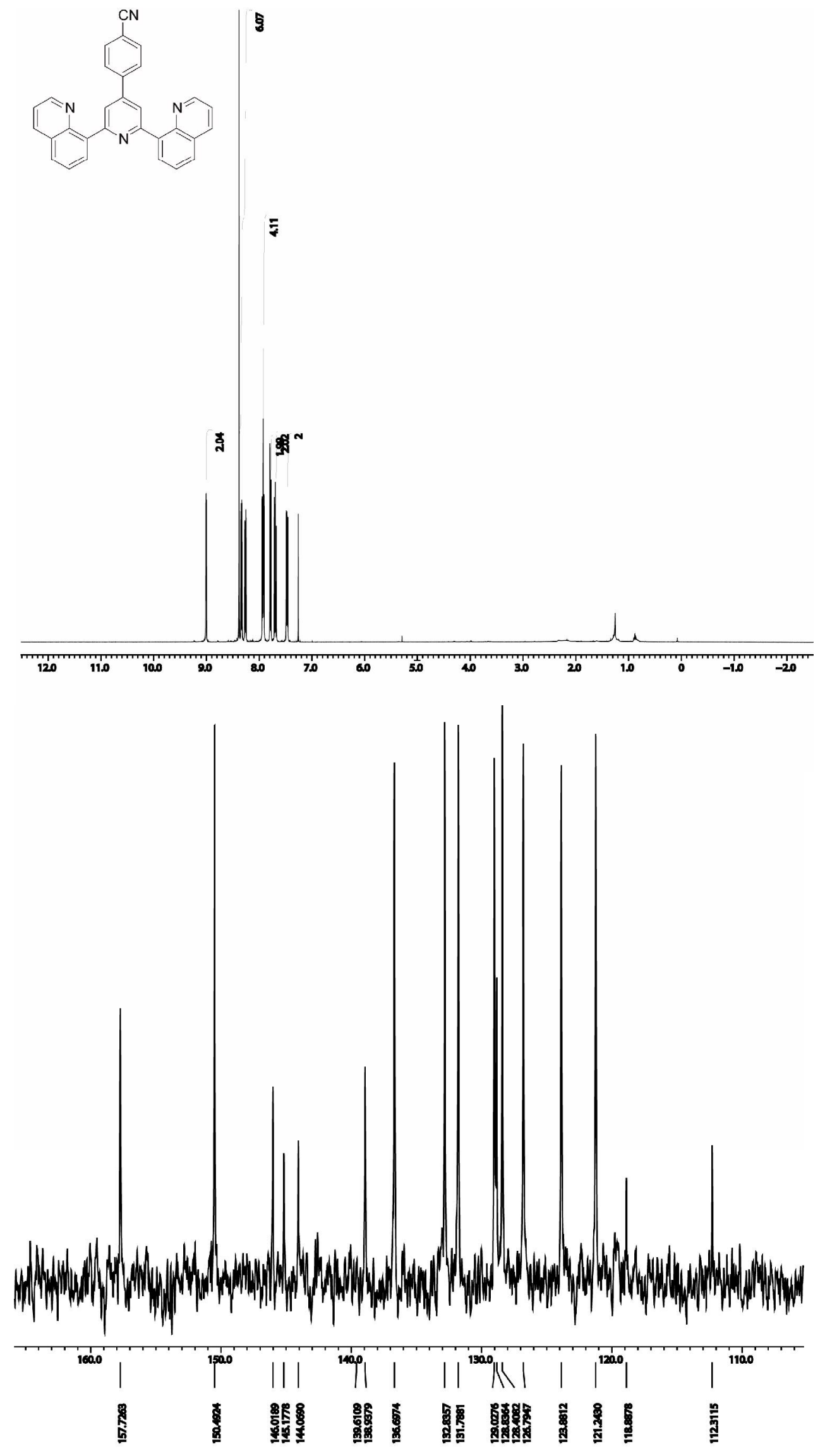

Compound $9\left(\mathrm{CDCl}_{3}\right)$. 

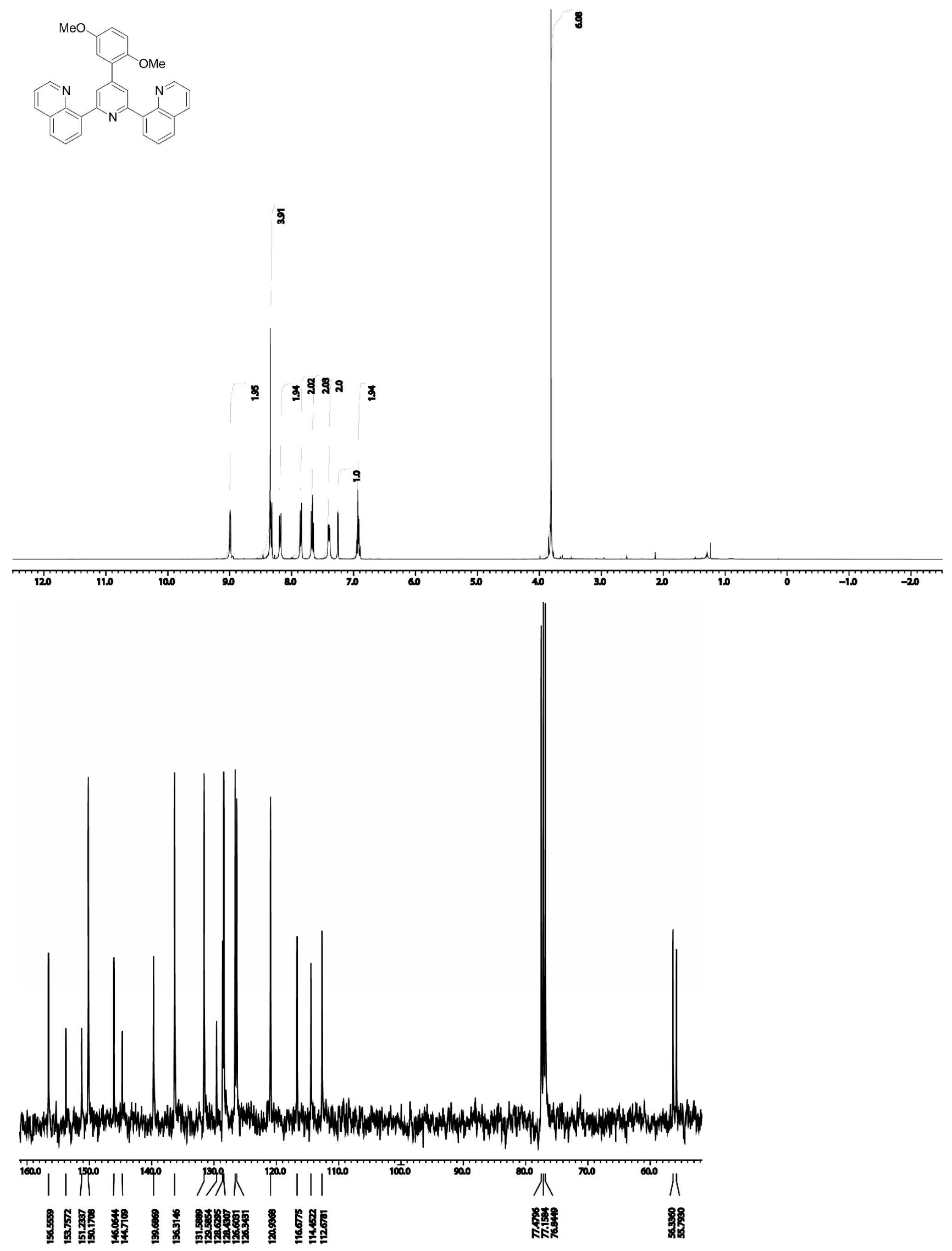

Compound $10\left(\mathrm{CDCl}_{3}\right)$. 

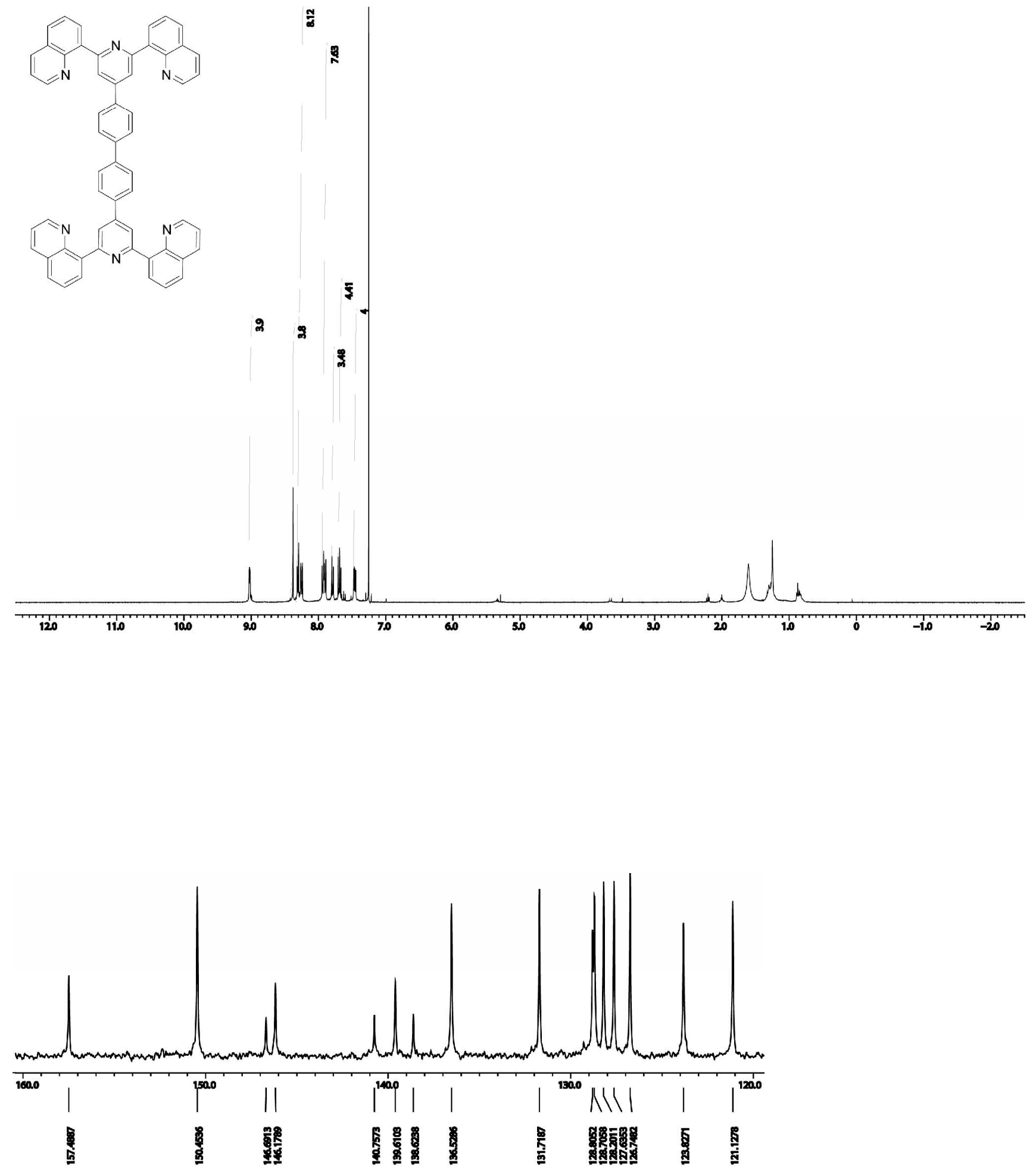

Compound $11\left(\mathrm{CDCl}_{3}\right)$. 


\section{Crystal structure determination}

Data collection for both $\mathbf{1}$ and $\mathbf{5}$ was carried out with a STOE IPDS using Mo-K $\alpha$ radiation $(\lambda \approx 0.71073 \AA)$ at ambient temperature $(293 \mathrm{~K})$. Details of the structure determination can be found in Table 1.

The structures were solved by direct methods using SHELXS97 ${ }^{4}$ where the majority of the nonhydrogen atoms could be found in the initial electron density map. The models were refined with least square calculations using the SHELXL97 program where also the residual atoms could be found from difference density maps. The hydrogen atoms were geometrically positioned and let to ride on the parent atoms through the least square calculations. All non-hydrogen atoms were refined with anisotropic displacement paramneters. Geometrical information not obtained from SHELXL97 was obtained from PLATON. ${ }^{5}$ Intermolecular contacts and hydrogen bonds are given in Table 2. Compound 1 crystallizes in a non-centro symmetric spacegroup but due to the absence of significant anomalous scatterer (i.e. heavy atoms) when using Mo-radiation the absolute configuration could not be determined. Compound $\mathbf{5}$ is crystallizing in a centro symmetric space group, thus both handedness of the molecules are present. 
Table 1. Crystallographic Data of 1 and 5.

\begin{tabular}{|c|c|c|}
\hline Compound & 1 & 5 \\
\hline Formula & $\mathrm{C}_{23} \mathrm{H}_{15} \mathrm{~N}_{3}$ & $\mathrm{C}_{23} \mathrm{H}_{16} \mathrm{~N}_{4}$ \\
\hline $\mathrm{M} / \mathrm{g} \cdot \mathrm{mole}^{-1}$ & 333.38 & 348.40 \\
\hline Crystal system & Trigonal & Monoclinic \\
\hline Space group & P 31 (nr. 144) & P $2{ }_{1} / \mathrm{c}($ nr. 14$)$ \\
\hline a / $\AA$ & $13.4160(7)$ & $7.5535(11)$ \\
\hline $\mathrm{b} / \AA ̊$ & $13.4160(7)$ & $21.7257(19)$ \\
\hline c / $\AA$ & $8.1117(5)$ & $11.1055(17)$ \\
\hline$\alpha /{ }^{\circ}$ & 90 & 90 \\
\hline$\beta / \circ$ & 90 & 104.19(2) \\
\hline$\gamma / 0$ & 120 & 90 \\
\hline $\mathrm{V} / \AA^{3}$ & $1264.4(1)$ & $1766.8(4)$ \\
\hline $\mathrm{Z}$ & 3 & 4 \\
\hline $\mathrm{F}(000)$ & 522 & 728 \\
\hline$D_{x} / g \cdot \mathrm{cm}^{-3}$ & 1.314 & 1.310 \\
\hline$\mu / \mathrm{mm}^{-1}$ & 0.079 & 0.080 \\
\hline Crystal size / mm & $0.10 \cdot 0.15 \cdot 0.30$ & $0.10 \cdot 0.12 \cdot 0.20$ \\
\hline $2 \theta_{\max } / \circ$ & 50.0 & 50.0 \\
\hline $\mathrm{R}_{\text {int }}, \mathrm{N}_{\text {meas }}, \mathrm{N}_{\text {unique }}$ & $0.087,8916,1473$ & $0.276,12147,3085$ \\
\hline $\mathrm{N}_{\mathrm{obs}}, \mathrm{N}_{\mathrm{par}}$ & 1273,236 & 795,245 \\
\hline wR2(all data), R1(obs data), $S$ & $0.0763,0.0320,1.00$ & $0.2264,0.0824,0.77$ \\
\hline Significance criterion & $\mathrm{I} \geq 2 \sigma(\mathrm{I})$ & $\mathrm{I} \geq 2 \sigma(\mathrm{I})$ \\
\hline Min and max res. dens. / e $\cdot \AA^{-3}$ & $-0.11-0.11$ & $-0.17-0.20$ \\
\hline
\end{tabular}


The shortest intermolecular interactions between center of gravity $\left(C_{g}\right)$ of different rings in $\mathbf{1}$ are 3.843(2) $\AA$, a distance found between $\mathrm{C}_{\mathrm{g}}\left(\right.$ ring-2) $-\mathrm{C}_{\mathrm{g}}\left(\right.$ ring-3) $[-\mathrm{y}, \mathrm{x}-\mathrm{y},-2 / 3+\mathrm{z}]$ and $\mathrm{C}_{\mathrm{g}}\left(\right.$ ring-3) $-\mathrm{C}_{\mathrm{g}}($ ring-2) $[-\mathrm{x}+\mathrm{y},-\mathrm{x}, 2 / 3+\mathrm{z}]$. The ring-2 constitutes N13-C12-C11-C16-C15-C14 (see manuscript text) and the ring-3 constitutes N23-C22-C21-C26-C25-C24. Also, a C-H...C $\mathrm{C}_{\mathrm{g}}$ distance of 3.417(2) $\AA$ is present that may be of minor importance for the stabilization.

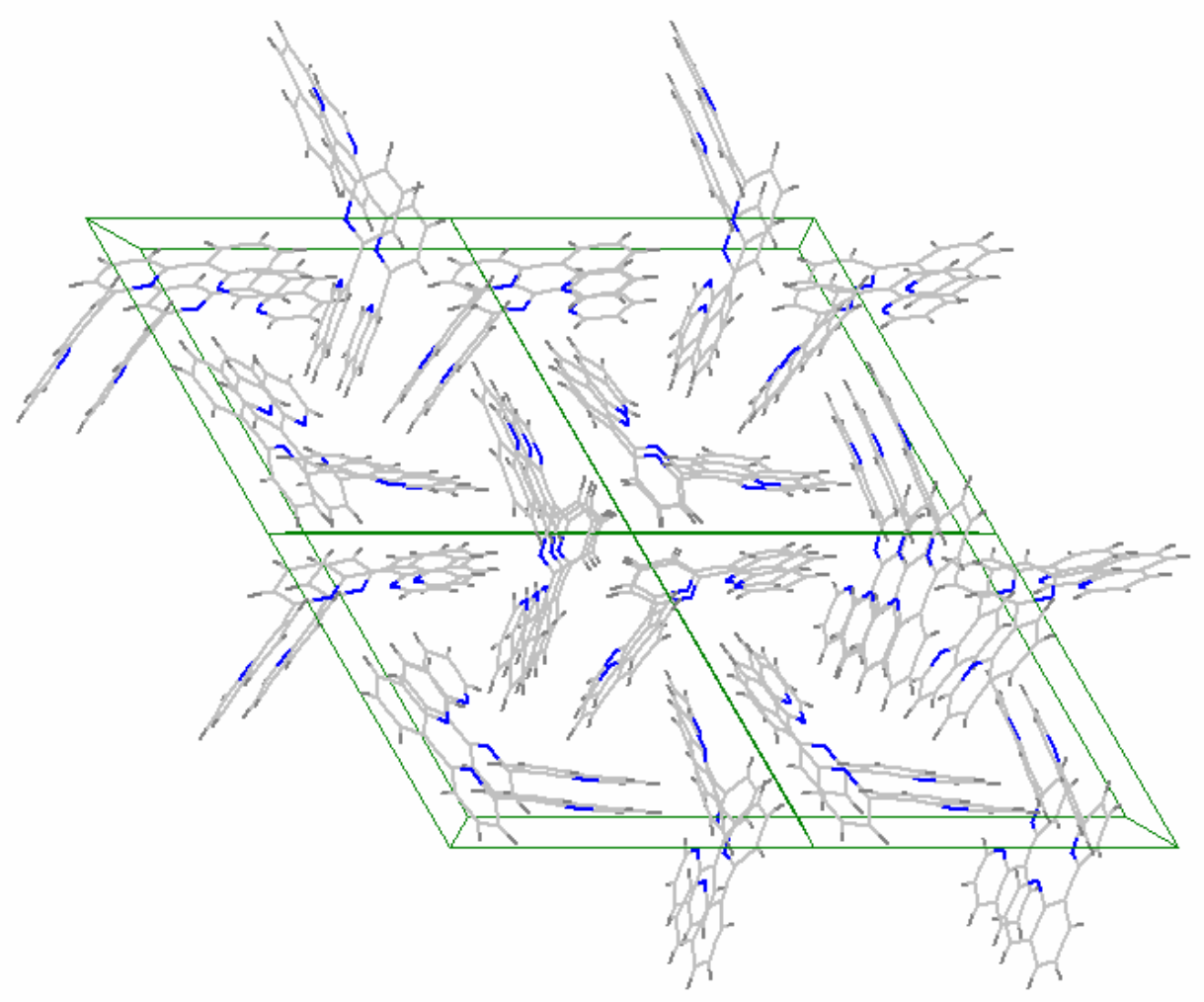

Packing view of $\mathbf{1}$. All intermolecular contacts are of van der Waals type. 
The torsional angles between the central pyridine and quinoline units are $-98.5^{\circ}$ (N1-C2-C7-C8) and 60.5 (N1-C6-C17-C18), respectively. The shortest intermolecular interaction between center of gravity of different rings in 5 is $3.540(4) \AA$, a distance found between $C_{g}\left(\right.$ ring-3) $-C_{g}($ ring-3) $[1-x, x 1-y, 3-z]$. The ring-3 constitutes N23-C22-C21-C26-C25-C24. The shortest C-H...C $\mathrm{C}_{\mathrm{g}}$ distance is 3.578(8) $\AA$. Hydrogen bonds data are given in Table 2.

\section{Table 2. Hydrogen Bond Data in 5.}

\begin{tabular}{lllll} 
D-H .. A & $\mathrm{d}(\mathrm{D}-\mathrm{H}) / \AA$ & $\mathrm{d}(\mathrm{H}-\mathrm{A}) / \AA$ & $\mathrm{d}(\mathrm{D} \ldots \mathrm{A}) / \AA$ & $\vee(\mathrm{D}-\mathrm{H} . . . \mathrm{A}) /{ }^{\circ}$ \\
$\mathrm{N} 27-\mathrm{H} 27 \mathrm{~A} . . \mathrm{N} 13$ [1-x,1-y,2-z] & 0.86 & 2.27 & $3.093(8)$ & 160 \\
$\mathrm{~N} 27-\mathrm{H} 27 \mathrm{~B} \ldots \mathrm{N} 23[1-\mathrm{x}, 1-\mathrm{y}, 2-\mathrm{z}]$ & 0.86 & 2.39 & $3.153(7)$ & 148 \\
\hline
\end{tabular}
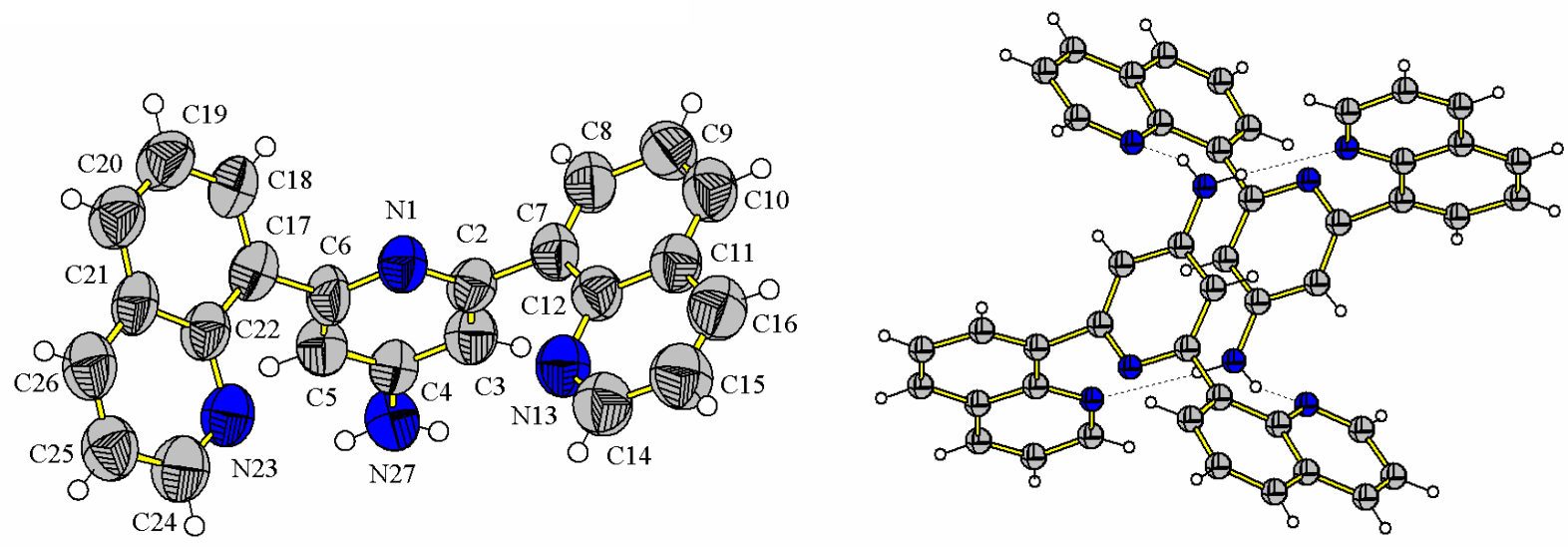

ORTEP view of $\mathbf{5}$ at $50 \%$ probability level.

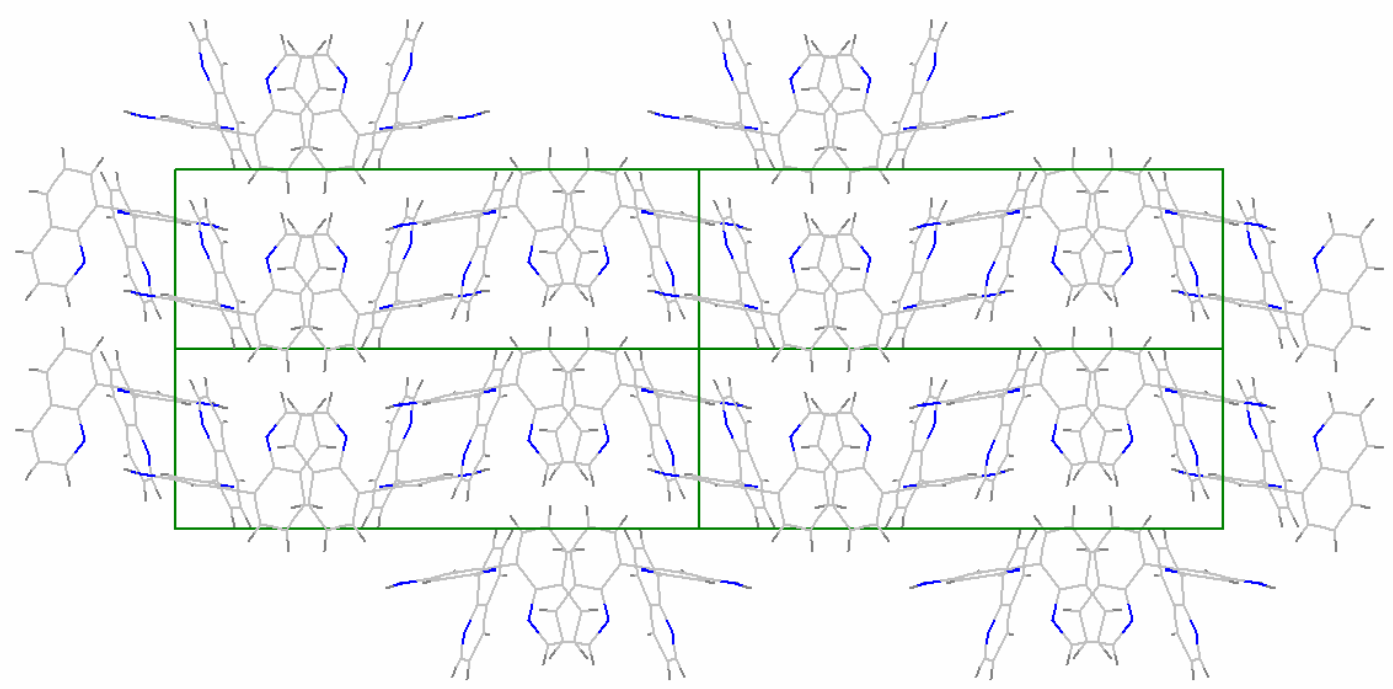

Packing view of $\mathbf{5}$ along the c-axis. 


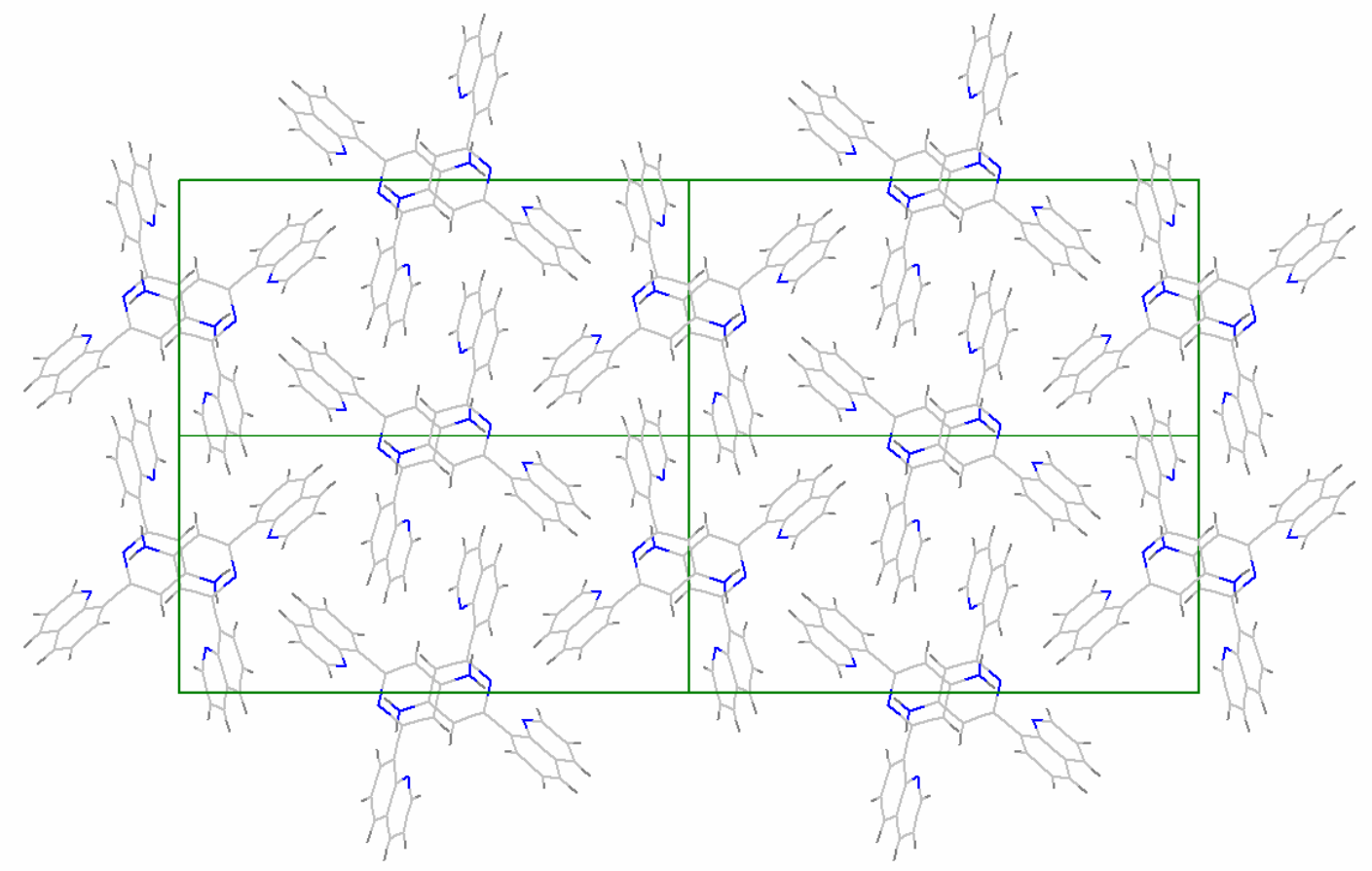

Packing view along the a-axis with dimers packed in the a-direction. 


\section{Geometry optimization of 1}

The figure below gives the heat of formation as a function of the torsional angle determining the conformation of the molecule. The geometry optimization calculations were done with MOPAC- $6^{6}$ using the AM1- hamiltonian.

The model for $\mathbf{1}$ used in the calculations was restricted to be completely symmetric regarding the torsion angles, $(\mathrm{N} 1-\mathrm{C} 2-\mathrm{C} 7-\mathrm{C} 8)=-(\mathrm{N} 1-\mathrm{C} 6-\mathrm{C} 17-\mathrm{C} 18)$. The experimental values of the torsion angles for $\mathbf{1}$ are very close to this symmetric model, and the experimental value observed in $\mathbf{1}$ is close to the calculated minimum. Compound $\mathbf{5}$ does not fulfill this symmetry criterion regarding the torsion angles as can be seen in the structure. One could note that the deviations for the torsion angles of $\mathbf{5}$ to the corresponding values of $\mathbf{1}$ correspond to an energy difference of approximately $2 \mathrm{kcal} \mathrm{mol}^{-1}$ compared to the value at the minimum of $\mathbf{1}$, a quantity that may well be compensated for by the energy stabilization due to the intermolecular hydrogen bonds present in the structure of $\mathbf{5}$.

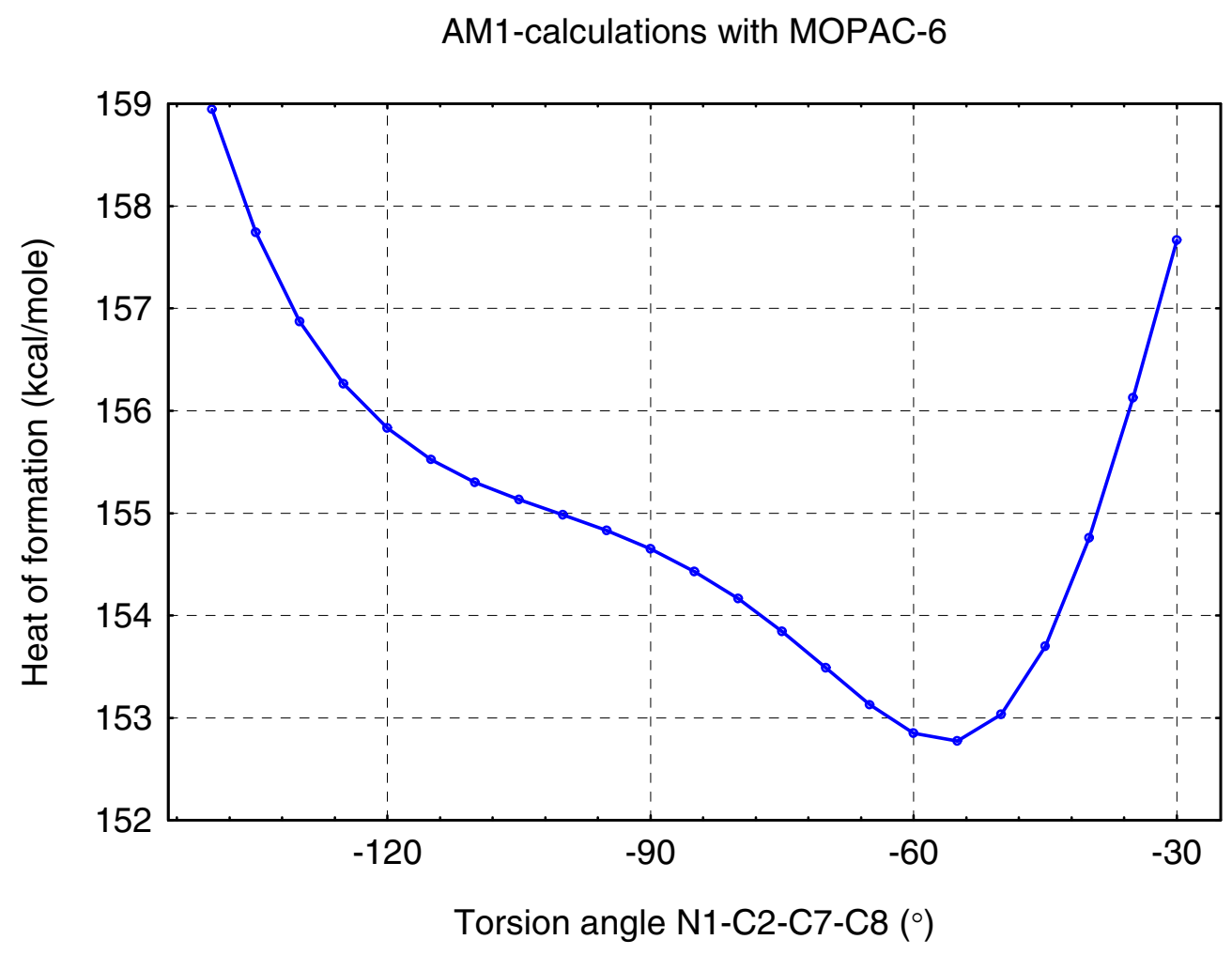




\section{References}

(1) Abrahamsson, M.; Jäger, M.; Österman, T.; Eriksson, L.; Persson, P.; Becker, H.-C.; Johansson, O.; Hammarström, L. J. Am. Chem. Soc. 2006, 128, 12616-12617.

(2) Taylor, R. J. Chem. Soc. B 1971, 2382-2387.

(3) Nilsson, S.; Wetterhall, J.; Bergquist, J.; Nyholm, L.; Markides, K. Rapid Commun. Mass Spectrom. 2001, 15, 1997-2000.

(4) Sheldrick, G. M. 1997, SHELXS97 and SHELXL97, University of Göttingen, Göttingen, Germany.

(5) Spek, A. L. J. Appl. Crystallogr. 2003, 36, 7-13.

(6) Stewart, J. J. P. 1990, MOPAC-6 public domain version, Frank J. Seiler Research Laboratory, United States Air Force Academy, CO 80840, USA. 